\title{
Use of mineral magnetic concentration data as a particle size proxy: A case study using marine, estuarine and fluvial sediments in the Carmarthen Bay area, South Wales, U.K.
}

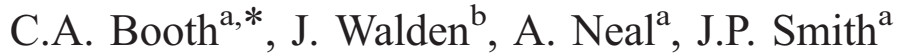 \\ ${ }^{a}$ Environmental and Analytical Science Division, Research Institute in Advanced Technologies (RIATec), The University of Wolverhampton, \\ Wulfruna Street, Wolverhampton, West Midlands WV1 1SB, UK \\ ${ }^{\mathrm{b}}$ School of Geography and Geosciences, University of St Andrews, Irvine Building, North Street, St Andrews, Fife KY16 9AL, UK
}

Received 4 October 2002; received in revised form 31 August 2004; accepted 10 December 2004

Available online 3 March 2005

\begin{abstract}
Compositional (non-magnetic) data can correlate strongly with particle size, which deems it appropriate as a particle size proxy and, therefore, a reliable means of normalising analytical data for particle size effects. Previous studies suggest magnetic concentration parameters represent an alternative means of normalising for these effects and, given the speed, low-cost and sensitivity of the measurements may, therefore, offer some advantages over other compositional signals. In this work, contemporary sediments from a range of depositional environments have been analysed with regard to their mineral magnetic concentration and textural characteristics, to observe if the strength and nature of the relationship identified in previous studies is universal. Our data shows magnetic parameters $\left(\chi_{\mathrm{LF}}, \chi_{\mathrm{ARM}}\right.$ and SIRM) possess contrasting relationships with standard textural parameters for sediment samples collected from marine (Carmarthen Bay), estuarine (Gwendraeth Estuary) and fluvial (Rivers Gwendraeth Fach and Gwendraeth Fawr) settings. Magnetic concentrations of sediments from both the marine and estuarine environments are highly influenced by the magnetic contribution of finer particle sizes; Gwendraeth Fawr River sediments are influenced by the magnetic contribution of coarser particle sizes, while sediments from the Gwendraeth Fach River are not influenced significantly by any variations in textural properties. These results indicate mineral magnetic measurements have considerable potential as a particle size proxy for particular sedimentary environments, which in certain instances could be useful for geochemical, sediment transport, and sediment provenance studies. However, the data also highlight the importance of fully determining the nature of the relationship between sediment particle size and magnetic properties before applying mineral magnetic data as a particle size proxy.
\end{abstract}

(c) 2005 Elsevier B.V. All rights reserved.

Keywords: Environmental magnetism; Sediment texture; Gwendraeth Estuary; Gwendraeth Fach River; Gwendraeth Fawr River

\footnotetext{
* Corresponding author. Tel.: +44 1902 322410; fax: +44 1902322714.

E-mail address: c.booth@wlv.ac.uk (C.A. Booth).
} 


\section{Introduction}

Mineral magnetic measurements are now considered a routine form of analysis when investigating the compositional properties of rocks, sediments and soils (Thompson and Oldfield, 1986; Walden et al., 1999; Maher and Thompson, 1999). The technique has been applied to various depositional environments (e.g. Arkell et al., 1983; Oldfield et al., 1985, 1999; White et al., 1997; Walden et al., 1995, 1997; Schmidt et al., 1999; Wheeler et al., 1999). Many of the studies have explored the relationship between mineral magnetic measurements and chemical/physical properties of sediments and soils (Oldfield et al., 1985; Oldfield and Yu, 1994; Clifton et al., 1997, 1999; Chan et al., 1998; Petrovsky et al., 1998; Xie et al., 1999, 2000; Booth, 2002). Based on these investigations, mineral magnetic measurements have been identified as a suitable tool for determining sediment provenance (Oldfield and Yu, 1994; Booth, 2002), sediment transport pathways (Lepland and Stevens, 1996), and also to serve as a proxy for geochemical, radioactivity, organic matter content and particle size data (Bonnett et al., 1988; Oldfield et al., 1993; Hutchinson and Prandle, 1994; Clifton et al., 1997, 1999; Xie et al., 1999, 2000; Zhang et al., 2001).

It is widely established that sediment-related analytical data can be strongly affected by particle size effects. For instance, generally, the finer a sediment the greater its concentration of both natural and anthropogenic pollutants (e.g. its trace metal concentration (Forstner and Salomons, 1980; Salomons and Forstner, 1980; Thorne and Nickless, 1981; Loring, 1990), radionuclide content (Aston et al., 1985; Bonnett et al., 1988; Oldfield et al., 1993; Clifton et al., 1997, 1999; McCubbin et al., 2000) or polychlorinated biphenyls (PCBs) quantity (Klamer et al., 1990; Camacho-Ibar and McEvoy, 1996). Typically, this is due to finer grained sediments possessing larger specific surface areas, surface charges and cation exchange capacities, which enhance the extent of their preferential chemical adsorption. This non-uniform distribution of pollutants over the range of particle size classes causes variations in the chemical composition of sediment samples. To directly compare samples of different particle sizes, it is thus necessary to correct for particle size effects.

Normalisation is a common process to compensate for particle size and mineralogical differences in sediments and soils. A range of correction procedures has been developed to minimise these effects. Popular approaches tend to normalise data either relative to the abundance of a specific particle size interval class or to carry out their analyses on a specifically separated particle size fraction (e.g. $<16 \mu \mathrm{m}$ (Klamer et al., 1990), <20 $\mu \mathrm{m}$ (Ackermann, 1980; Ackermann et al., 1983; Christiansen et al., 2002), <63 $\mu \mathrm{m}$ (Salomons and Forstner, 1980; Araujo et al., 1988; Klamer et al., 1990), $<100 \mu \mathrm{m}$ (Langston, 1986), <150 $\mu \mathrm{m}$ (Jones and Turki, 1997), <250 $\mu \mathrm{m}$ (Hornung et al., 1989)). Although these methods can be considered reliable and advantageous, they require additional and, in the latter case, time-consuming laboratory work.

Other techniques have also been adopted involving a correction factor for an inert or organic material (Thomas, 1972; Williams et al., 1978; Cauwet, 1987; Ergin et al., 1996; Camacho-Ibar and McEvoy, 1996; Fernandez Caliani et al., 1997; Russell et al., 2001) or by comparison with 'conservative' elements (i.e. elements with strong correlations to particle size, but themselves are not pollutants), such as aluminium (de Groot et al., 1982; Ergin et al., 1996), iron (Lapp and Balzer, 1993), caesium (Ackermann, 1980), or rubidium (Middleton and Grant, 1990). In general, these approaches also employ extrapolation from regression curves or sometimes entail a mathematical formulation of correcting particle size effects after analysis of bulk samples (de Groot et al., 1982; Covelli and Fontolan, 1997; Szava-Kovats, 2002).

Where a particle size proxy can be measured in an efficient fashion (that is, shorter analysis time or lower cost than determination of the particle size distribution or preparation of specific size fractions for analysis), it can offer potential advantages. However, to assess the appropriateness of an analytical technique as an efficient particle size proxy and as an accurate means of normalising data, it is necessary that the nature of the relationship between the proposed parameters and particle size follow a universal pattern (like those of trace metals, radionuclides and PCBs with particle size). 

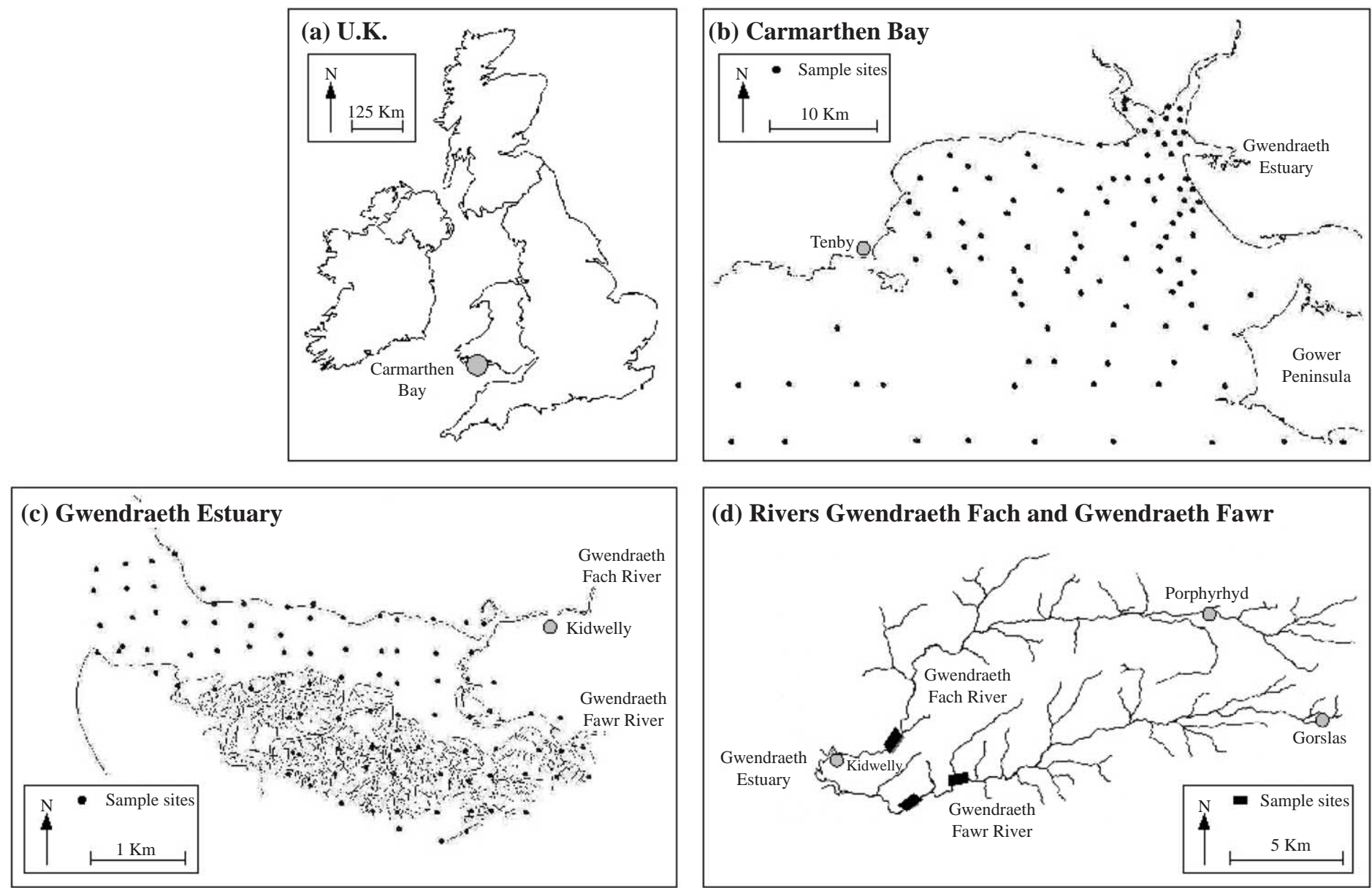

Fig. 1. Location maps (a) U.K.; (b) Carmarthen Bay; (c) Gwendraeth Estuary; and (d) the rivers Gwendraeth Fach and Gwendraeth Fawr. 
Given the combination of low-cost and sensitivity of the method, it can be argued that mineral magnetic measurements might have some considerable potential to act as a particle size proxy. The method is also rapid; bulk samples require little in the way of preparation and individual measurements of magnetic susceptibility $\left(\chi_{\mathrm{LF}}\right)$ can be made in approximately $1 \mathrm{~min}$, in either a laboratory or field setting. Previous workers have investigated this potential of the method. For example, Oldfield et al. (1993) has identified (a) that anhysteretic remanent magnetisation (ARM) measurements can be used to reflect the concentration of fine-grained magnetite $(<0.1 \mu \mathrm{m})$ in the clay fraction and (b) $\chi_{\mathrm{LF}}$ measurements can be used to infer the presence of coarser multi-domain magnetite $(>1.0 \mu \mathrm{m})$ in sands and coarse silts. In a more detailed investigation it was found that (a) $\chi_{\mathrm{LF}}$ was strongly associated with sands and medium silts, (b) susceptibility of ARM $\left(\chi_{\text {ARM }}\right)$ was strongly associated with clay and fine silts, and (c) saturated isothermal remanent magnetisation (SIRM) was strongly associated with very fine to medium silts (Clifton et al., 1999). More recently, Zhang et al. (2001) suggested that both percentage frequencydependent magnetic susceptibility $\left(\chi_{\mathrm{FD} \%}\right)$ and $\chi_{\mathrm{ARM}}$ can be used as a proxy for clay content.

In general, this evidence supports the inference that high magnetic concentration measurements can be associated with large amounts of fine-grained sediments and an inverse relationship with coarsegrained sediments. However, few studies have examined the relationships between mineral magnetic measurements and textural properties from a series of different, but related, sedimentary environments within a single field setting, to observe if the strength and nature of the relationship is universal.

This paper will explore two methodological issues. First, as in the earlier studies cited above, it will examine the extent to which particular mineral magnetic parameters are reliable indicators of differences in particle size. Second, the 'universality' principle that all sedimentary environments show the same relationship between mineral magnetic and particle size properties is considered by examining the relationships between mineral magnetic concentration measurements and textural properties in marine, estuarine, and fluvial sediments within a single field setting (Fig. 1).

\section{Methodology}

Ongoing research by the current authors within the Carmarthen Bay area, South Wales, U.K. provided a suitable database of field samples with which to examine these methodological issues (Booth, 2002). This previous work provided a suitable field context, with existing knowledge of the sediment transport environment, tidal patterns, bathymetry and sediment sources (Jones, 1977; Evans and Thompson, 1979; Jago, 1980; Barrie, 1981; Al-Ghadban, 1986; Collins, 1987; Mercer, 1990; Jago and Hardisty, 1984; McLaren, 1999; Velegrakis et al., 1999; Booth, 2002). The field setting includes large areas dominated by marine (Carmarthen Bay), estuarine (Gwendraeth Estuary) and fluvial (Gwendraeth Fach and Gwendraeth Fawr Rivers) sediments within the overall sedimentary system (Fig. 1), allowing the second methodological issue outlined above to be examined.

A total of 308 samples were collected and analysed. Marine samples were collected from Carmarthen Bay $(n=113)$ using a Shipek grab sampler, which retrieves the uppermost centimetres of seabed sediment. Representative samples from each successful grab were stored in labelled, selfseal plastic sample bags (McLaren, 1999). Estuarine samples from the Gwendraeth Estuary $(n=95)$ and fluvial samples from the Gwendraeth Fach $(n=50)$ and Gwendraeth Fawr $(n=50)$ rivers were collected using a technique previously employed by French (1993). This involved using the edge of a clean plastic trowel that was scraped across an exposed sediment surface to remove only the top few millimetres of sediment. The sediment was then transferred into clean, pre-labelled, self-seal, plastic bags, until samples yielding $\sim 100-150$ g dry weight was obtained. Samples of this size allowed for replicate analyses to be conducted and for other types of analysis to be performed as required.

Textural properties of the sediments were measured by laser diffraction using a Malvern Mastersizer Long-bed X. The technique allows rapid and accurate measurement of particle sizes within the 
0.1-2000 $\mu \mathrm{m}$ range (Syvitski, 1991). All macroscopic organic matter and shell fragments were removed from representative sub-samples before being dampened by the dropwise addition of a standard chemical solution (40 g of sodium hexametaphosphate $\left(\left(\mathrm{NaPO}_{3}\right)_{6}\right)$ per litre of distilled water (Zhao et al., 1999) to help disperse aggregate particles. To ensure complete disaggregation, each sediment slurry was then subjected to ultrasonic

\section{Table 1}

Mineral magnetic parameters discussed in the text and their basic interpretation (after Dearing, 1999; Thompson and Oldfield, 1986; Maher, 1988; Walden et al., 1999)

\begin{tabular}{|c|c|}
\hline$\underline{\text { Parameters }}$ & Interpretation \\
\hline $\begin{array}{c}\chi_{\mathrm{LF}}\left(\times 10^{-7}\right. \\
\left.\mathrm{m}^{3} \mathrm{~kg}^{-1}\right)\end{array}$ & $\begin{array}{l}\text { Initial low field mass specific } \\
\text { magnetic susceptibility }\left(\chi_{\mathrm{LF}}\right) \\
\text { is measured within a small } \\
\text { magnetic field and is reversible } \\
\text { (no remanence is induced). } \\
\text { Its value is roughly proportional } \\
\text { to the concentration of ferrimagnetic } \\
\text { minerals within the sample, although } \\
\text { in materials with little or no ferrimagnetic } \\
\text { component and a relatively large } \\
\text { antiferromagnetic component, } \\
\text { the latter may dominate the signal. }\end{array}$ \\
\hline $\begin{array}{c}\chi_{\text {ARM }}\left(\times 10^{-7}\right. \\
\left.\mathrm{m}^{3} \mathrm{~kg}^{-1}\right)\end{array}$ & $\begin{array}{l}\text { Susceptibility of Anhysteretic } \\
\text { Remanent Magnetisation ( } \chi_{\text {ARM }} \text { ) } \\
\text { is roughly proportional to the } \\
\text { concentration of ferrimagnetic grains } \\
\text { in the } 0.02-0.5 \mu \mathrm{m} \text { (stable single domain) } \\
\text { size range. For this work, ARM was } \\
\text { induced in the samples by combining a } \\
\text { peak AF field of } 100 \mathrm{mT} \text { with a DC } \\
\text { biasing field of } 0.04 \mathrm{mT} \text { and the final } \\
\text { result expressed as mass specific ARM } \\
\text { (Maher, 1988). }\end{array}$ \\
\hline $\begin{array}{l}\text { SIRM }\left(10^{-5}\right. \\
\left.\operatorname{Am}^{2} \mathrm{~kg}^{-1}\right)\end{array}$ & $\begin{array}{l}\text { Saturation Isothermal Remanent } \\
\text { Magnetisation (SIRM) is the highest } \\
\text { amount of magnetic remanence that } \\
\text { can be produced in a sample by applying } \\
\text { a large magnetic field. It is measured } \\
\text { on a mass specific basis. In this study a } \\
\text { 'saturating' field of } 800 \mathrm{mT} \text { has been } \\
\text { used and this will produce saturation in } \\
\text { most mineral types (except some } \\
\text { antiferromagnetic minerals). The value of } \\
\text { SIRM is related to concentrations of all } \\
\text { remanence-carrying minerals in the } \\
\text { sample, but is also dependent upon the } \\
\text { assemblage of mineral types and their } \\
\text { magnetic grain size. }\end{array}$ \\
\hline
\end{tabular}

dispersion in a Malvern MSX17 sample presentation unit. For greater precision, the mean of five replicate analyses was measured with a mixed refractive indices presentation setting. A standard range of textural parameters was calculated (Tucker, 1991). As in the studies of Clifton et al. (1997, 1999), these included the quantity of sand, silt and clay class sizes (expressed as percentages). Throughout this work, the Malvern instrumentation was regularly validated using latex beads of known size, to confirm it was performing to traceable standards.

For mineral magnetic analysis, all samples were subjected to the same preparation and analysis procedure, following Walden (1999), in which $20 \mathrm{~g}$ of each bulk sample was allowed to dry at room temperature $\left(<40{ }^{\circ} \mathrm{C}\right)$ and were then weighed, packed in $10 \mathrm{ml}$ plastic pots and immobilised with clean sponge foam and tape prior to analysis. A standard range of magnetic parameters was measured on all samples. Initial, low-field, low-frequency, mass specific, magnetic susceptibility $\left(\chi_{\mathrm{LF}}\right)$ was measured using a Bartington MS2 susceptibility meter. Anhysteretic remanence magnetisation (ARM) was imparted by a Molspin A.F. demagnetiser with an ARM attachment. ARM created within the sample was measured using a Molspin 1A magnetometer and then demagnetised using the A.F. demagnetiser. Values were then converted to give the mass specific susceptibility of ARM $\left(\chi_{\text {ARM }}\right)$. Samples were then exposed to a series of successively larger field sizes up to a maximum of $800 \mathrm{mT}$, followed by a series of successively larger fields in the opposite direction (backfields). After each 'forward' and 'reverse' field, the isothermal remanent magnetisation (IRM) of the sample was measured using the magnetometer. Table 1 provides a basic description and interpretation of each of the main parameters derived from these measurements.

\section{Results}

Summary mineral magnetic and texture data for the samples are presented in Tables 2 and 3 . The $\chi_{\mathrm{LF}}$ values show considerable variation, with Carmarthen Bay $\left(0.17-2.72 \times 10^{-7} \mathrm{~m}^{3} \mathrm{~kg}^{-1}\right)$, the Gwendraeth Estuary $\left(0.32-4.94 \times 10^{-7} \mathrm{~m}^{3} \mathrm{~kg}^{-1}\right)$ and the Gwen- 
Table 2

Mineral magnetic concentration data for Carmarthen Bay $(n=113)$, Gwendraeth Estuary $(n=95)$, Gwendraeth Fach River $(n=50)$ and Gwendraeth Fawr River $(n=50)$

\begin{tabular}{llrlr}
\hline $\begin{array}{l}\text { Sedimentary } \\
\text { environments }\end{array}$ & Parameters & $\chi_{\text {LF }}$ & $\chi_{\text {ARM }}$ & SIRM \\
\hline Carmarthen & Mean & 0.86 & 0.09 & 114.55 \\
Bay & S.D. & 0.51 & 0.10 & 67.11 \\
Gwendraeth & Mean & 2.10 & 0.66 & 309.51 \\
Estuary & S.D. & 1.22 & 0.54 & 192.44 \\
Gwendraeth & Mean & 11.01 & 0.51 & 2013.99 \\
Fach River & S.D. & 6.10 & 0.25 & 1033.65 \\
Gwendraeth & Mean & 3.01 & 0.25 & 492.48 \\
Fawr River & S.D. & 0.50 & 0.02 & 112.46 \\
\hline
\end{tabular}

draeth Fawr River $\left(2.32-4.39 \times 10^{-7} \mathrm{~m}^{3} \mathrm{~kg}^{-1}\right)$ exhibiting low to moderate concentrations of magnetic minerals, while the Gwendraeth Fach River (4.29$27.17 \times 10^{-7} \mathrm{~m}^{3} \mathrm{~kg}^{-1}$ ) shows a moderate to high concentration of magnetic minerals.

The $\chi_{\text {ARM }}$ values indicate that the Carmarthen Bay $\left(0.02-0.65 \times 10^{-7} \mathrm{~m}^{3} \mathrm{~kg}^{-1}\right)$ samples contain low to moderate concentrations of stable single domain magnetite. The Gwendraeth Fach and Gwendraeth Fawr Rivers $\left(0.24-1.19 \times 10^{-7} \mathrm{~m}^{3} \mathrm{~kg}^{-1}\right.$ and $0.21-$ $1.19 \times 10^{-7} \mathrm{~m}^{3} \mathrm{~kg}^{-1}$, respectively) contain moderate to high $\chi_{\text {ARM }}$ concentrations. The Gwendraeth Estuary $\left(0.04-1.80 \times 10^{-7} \mathrm{~m}^{3} \mathrm{~kg}^{-1}\right)$ exhibits a very variable concentration of stable single domain magnetic minerals with low to very-high $\chi_{\text {ARM }}$ values.

SIRM values show variations similar to $\chi_{\mathrm{LF}}$; Carmarthen Bay $\left(25.8-404.4 \times 10^{-5} \mathrm{Am}^{2} \mathrm{~kg}^{-1}\right)$, the Gwendraeth Estuary $\left(39.3-770.2 \times 10^{-5} \mathrm{Am}^{2} \mathrm{~kg}^{-1}\right)$ and Gwendraeth Fawr River $\left(341.0-765.6 \times 10^{-5}\right.$ $\mathrm{Am}^{2} \mathrm{~kg}^{-1}$ ) contain low to moderate concentrations

Table 3

Textural data for Carmarthen Bay $(n=113)$, Gwendraeth Estuary $(n=95)$, Gwendraeth Fach River $(n=50)$ and Gwendraeth Fawr River $(n=50)$

\begin{tabular}{llrrr}
\hline $\begin{array}{l}\text { Sedimentary } \\
\text { environments }\end{array}$ & Parameters & Sand & Silt & Clay \\
\hline Carmarthen & Mean & 93.20 & 5.98 & 0.83 \\
$\quad$ Bay & S.D. & 11.25 & 10.00 & 1.27 \\
Gwendraeth & Mean & 49.80 & 45.73 & 4.47 \\
Estuary & S.D. & 35.13 & 32.17 & 3.31 \\
Gwendraeth & Mean & 77.91 & 20.47 & 1.62 \\
Fach River & S.D. & 14.35 & 13.45 & 1.06 \\
Gwendraeth & Mean & 51.07 & 44.58 & 4.35 \\
Fawr River & S.D. & 17.22 & 16.09 & 1.40 \\
\hline
\end{tabular}

of all remanence-carrying magnetic minerals. By contrast, the Gwendraeth Fach River (826.0$4779.0 \times 10^{-5} \mathrm{Am}^{2} \mathrm{~kg}^{-1}$ ) shows a moderate to high concentration of all remanence-carrying magnetic minerals.

Table 4 shows the Pearson's correlation coefficient values $(r)$ between the mineral magnetic concentration parameters and standard textural parameters, grouped according to their sedimentary environment. Significant negative correlations exist between each of the mineral magnetic concentration parameters and the percentage sand for both Carmarthen Bay and the Gwendraeth Estuary. If $\chi_{\text {ARM }}$ is excluded, the same is also true for the Gwendraeth Fawr River. However, the nature of the Gwendraeth Fawr River correlations (positive with respect to percentage sand) is the reverse of those for Carmarthen Bay and the Gwendraeth Estuary. Irrespective of this, each of these relationships are in contrast to those observed for the Gwendraeth Fach River, which shows no significant relationship between any of the mineral magnetic concentration and textural parameters. With respect to the Gwendraeth Fach River, it is also apparent that each textural parameter shows differing strengths of correlation with each of the magnetic concentration parameters.

Fig. 2a-d show bivariate scatter plots of sand content $(\%)$ versus $\chi_{\mathrm{LF}}\left(\times 10^{-7} \mathrm{~m}^{3} \mathrm{~kg}^{-1}\right)$ for each

Table 4

Mineral magnetic concentration and texture correlation coefficient values $(r)$ for Carmarthen Bay $(n=113)$, Gwendraeth Estuary $(n=95)$, Gwendraeth Fach River $(n=50)$ and Gwendraeth Fawr River $(n=50)$

\begin{tabular}{clrrr}
\hline $\begin{array}{l}\text { Sedimentary } \\
\text { environments }\end{array}$ & Parameters & \multicolumn{1}{l}{$\chi_{\mathrm{LF}}$} & \multicolumn{1}{l}{$\chi_{\mathrm{ARM}}$} & \multicolumn{1}{l}{ SIRM } \\
\hline Carmarthen & Sand & $-0.495^{*}$ & $-0.957^{*}$ & $-0.603^{*}$ \\
Bay & Silt & $0.498^{*}$ & $0.958^{*}$ & $0.605^{*}$ \\
& Clay & $0.470^{*}$ & $0.943^{*}$ & $0.578^{*}$ \\
Gwendraeth & Sand & $-0.923^{*}$ & $-0.900^{*}$ & $-0.911^{*}$ \\
Estuary & Silt & $0.924^{*}$ & $0.901^{*}$ & $0.913^{*}$ \\
& Clay & $0.818^{*}$ & $0.794^{*}$ & $0.799^{*}$ \\
Gwendraeth & Sand & $-0.125^{\mathrm{NS}}$ & $-0.161^{\mathrm{NS}}$ & $-0.128^{\mathrm{NS}}$ \\
Fach River & Silt & $0.121^{\mathrm{NS}}$ & $0.158^{\mathrm{NS}}$ & $0.123^{\mathrm{NS}}$ \\
& Clay & $0.165^{\mathrm{NS}}$ & $0.180^{\mathrm{NS}}$ & $0.164^{\mathrm{NS}}$ \\
Gwendraeth & Sand & $0.700^{*}$ & $-0.058^{\mathrm{NS}}$ & $0.829^{*}$ \\
Fawr River & Silt & $-0.707^{*}$ & $0.057^{\mathrm{NS}}$ & $-0.837^{*}$ \\
& Clay & $-0.479^{*}$ & $0.061^{\mathrm{NS}}$ & $-0.572^{*}$ \\
\hline
\end{tabular}

* Significant at $p<0.01$ level.

NS Not significant at $p<0.05$ level. 
(a) Carmarthen Bay

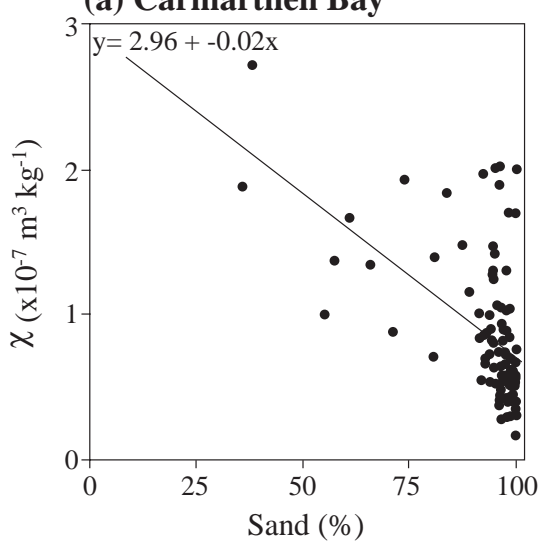

(c) Gwendraeth Fach River

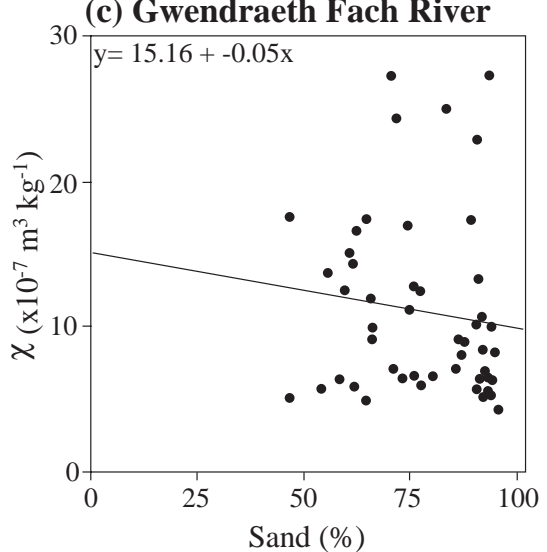

(b) Gwendraeth Estuary

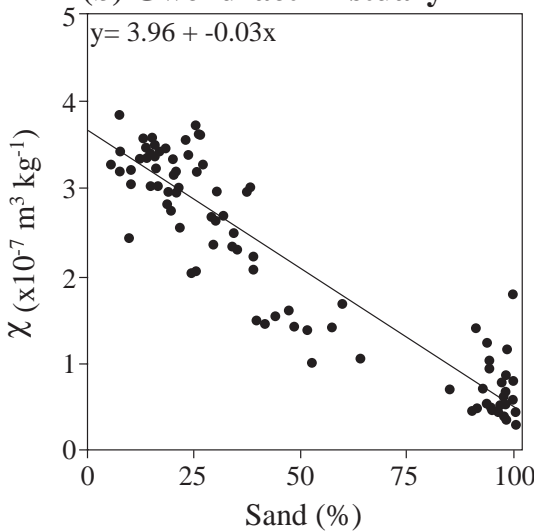

(d) Gwendraeth Fawr River

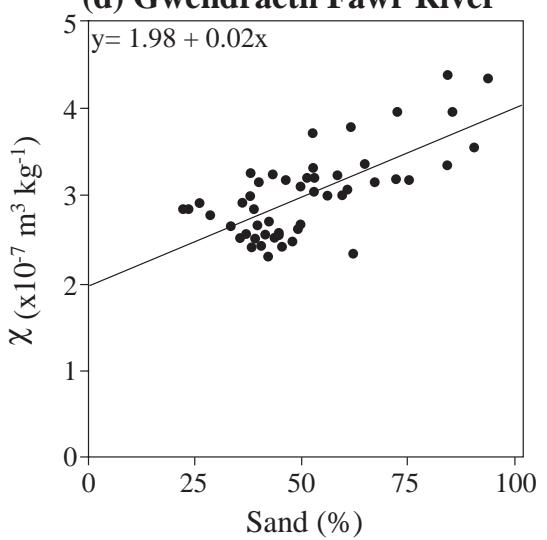

Fig. 2. Sand content as a function of $\chi_{\mathrm{LF}}$ in bulk sediment samples (a) Carmarthen Bay ( $n=113$ ); (b) Gwendraeth Estuary ( $n=95$ ); (c) Gwendraeth Fach River $(n=50)$; and (d) Gwendraeth Fawr River $(n=50)$.

of the sedimentary environments. Both the Gwendraeth Estuary and Gwendraeth Fawr River samples have relatively modest degrees of scatter around the line of best fit (Fig. $2 b$ and $d$ ). This suggests differences in the concentration of ferrimagnetic minerals and/or antiferromagnetic component in these samples could be used as a proxy for the proportion of sand, although care would be needed with the Gwendraeth Estuary samples as the data are clearly not normally distributed. In contrast, both Carmarthen Bay and the Gwendraeth Fach River samples, as suggested by lower correlations coefficients (Table 4), show greater scatter (Fig. 2a and c) and, while the relationship between sand content and $\chi_{\mathrm{LF}}$ is significant for the Carmarthen Bay sample set, the data distributions in Fig. 2a and c would not give high levels of confidence in susceptibility as a sand content proxy in either case. Fig. 3a-d show similar plots for sand content (\%) versus SIRM $\left(\times 10^{-5} \mathrm{Am}^{2} \mathrm{~kg}^{-1}\right)$. The relationships for each sample set are identical to those for $\chi_{\mathrm{LF}}$ and this suggests that for these sample sets at least, $\chi_{\mathrm{LF}}$ and SIRM are responding to the same magnetic component. In any further analyses of these sediments, only one of these two variables would need to be measured.

Fig. $4 \mathrm{a}-\mathrm{d}$ provide similar bivariate scatter plots of sand content $(\%)$ versus $\chi_{\text {ARM }}\left(\times 10^{-5} \mathrm{Am}^{2} \mathrm{~kg}^{-1}\right)$. In this case, the plots for the Carmarthen Bay and Gwendraeth Estuary samples (Fig. 4a and b) both appear to support a strong, negative relationship between the proportion of sand present and $\chi_{\text {ARM }}$, 

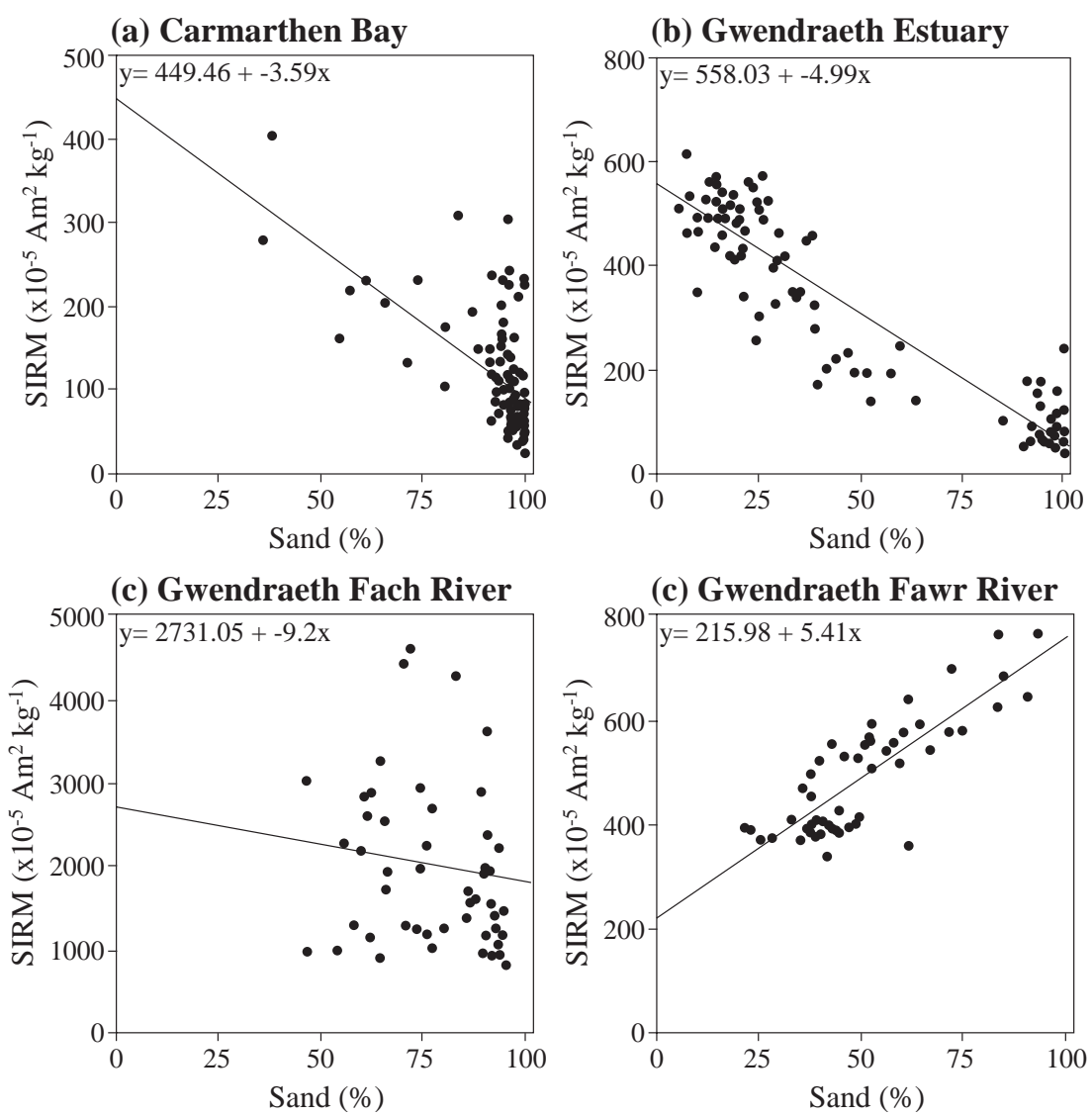

Fig. 3. Sand content as a function of SIRM in bulk sediment samples (a) Carmarthen Bay ( $n=113$ ); (b) Gwendraeth Estuary ( $n=95$ ); (c) Gwendraeth Fach River ( $n=50)$; and (d) Gwendraeth Fawr River $(n=50)$.

although the relationship for Gwendraeth Estuary is possibly non-linear. In contrast, variations in the concentration of ultrafine ferrimagnetic minerals of the samples in either the Gwendraeth Fach River or the Gwendraeth Fawr River do not appear to be influenced by differences in the proportion of sand (Fig. 4c and d).

\section{Discussion}

Previous magnetic studies of coastal and estuarine sediments (Bonnett et al., 1988; Clifton et al., 1999) have noted significant correlations between $\chi_{\mathrm{LF}}, \chi_{\mathrm{ARM}}$, SIRM and particle size. These studies have shown sand to correlate negatively with $\chi_{\mathrm{LF}}(r=-0.94), \chi_{\mathrm{ARM}}$ $(r=-0.81)$, but SIRM to be insignificant; silt to cor- relate positively with $\chi_{\mathrm{LF}}(r=0.96), \chi_{\mathrm{ARM}}(r=0.93)$ and $\operatorname{SIRM}(r=0.96)$; and clay to correlate positively with $\chi_{\text {LF }}(r=0.77), \chi_{\text {ARM }}(r=0.92)$ and SIRM $(r=0.81)$. When data presented here are compared to these earlier investigations, it is apparent that some of the correlations and trends observed are similar to previous studies (e.g. sand and $\chi_{\mathrm{ARM}}(r=-0.96)$, silt and $\chi_{\mathrm{LF}}$ $(r=0.92)$, clay and SIRM $(r=0.80))$. However, some differences also occur (e.g. sand and $\chi_{\text {ARM }}(r=-0.06)$, silt and $\chi_{\mathrm{LF}}(r=-0.71)$, clay and SIRM $\left.(r=-0.57)\right)$ in terms of both significance and nature (positive or negative) of the trends.

The hypothesis that the formal correlation identified between analytical data and textural variation (e.g. heavy metal concentration, radionuclide activity or PCBs content increasing as particle size decreases) means that the correction of particle size effects relies 

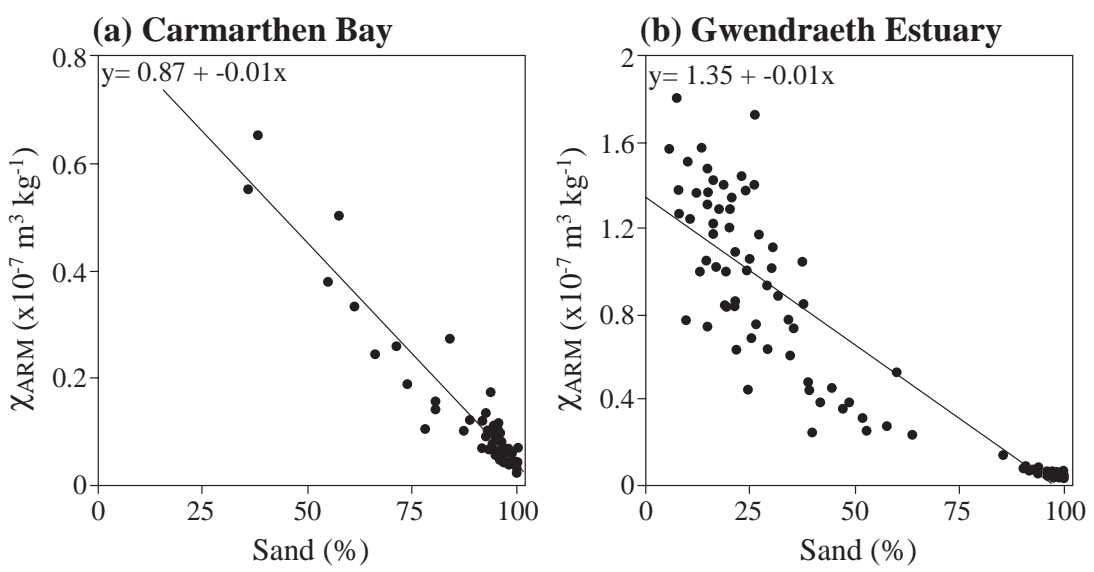

(c) Gwendraeth Fach River

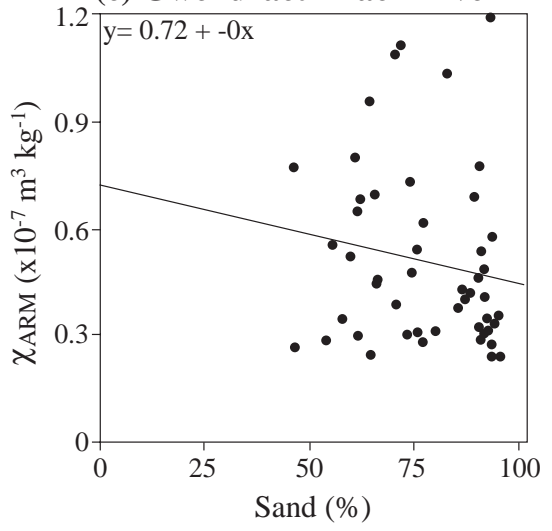

(d) Gwendraeth Fawr River

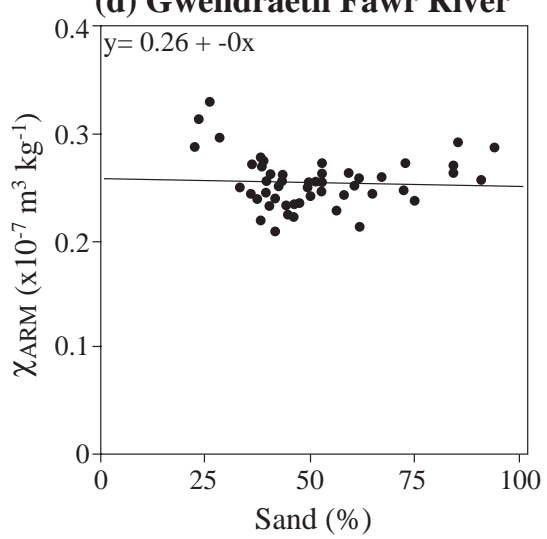

Fig. 4. Sand content as a function of $\chi_{\text {ARM }}$ in bulk sediment samples (a) Carmarthen Bay ( $n=113$ ); (b) Gwendraeth Estuary ( $n=95$ ); (c) Gwendraeth Fach River ( $n=50)$; and (d) Gwendraeth Fawr River $(n=50)$.

on the universal applicability of the relationship. However, based on data presented here, such a simple relationship does not exist for mineral magnetic concentration parameters. It would appear that it is only in certain sedimentary environments and specific settings that mineral magnetic measurements are appropriate for granulometric normalisation. Our data suggest $\chi_{\mathrm{LF}}$ and SIRM measurements are appropriate particle size proxies in the Gwendraeth Estuary and the Gwendraeth Fawr River, and that $\chi_{\text {ARM }}$ measurements form an appropriate particle size proxy in Carmarthen Bay and the Gwendraeth Estuary. In contrast, no mineral magnetic measurements are appropriate for normalising particle size effects in the Gwendraeth Fach River. Some of these trends agree with previous investigations (Bonnett et al., 1988; Clifton et al., 1999), which have emphasised the potential of mineral magnetic measurements as a simple, reliable, rapid, sensitive, inexpensive and nondestructive method of normalising for particle size. However, a cautionary note is required here as our relationships between mineral magnetic concentration and texture also indicate the association may not be as simple as previous work proposes.

It has been identified that Carmarthen Bay and the Gwendraeth Estuary have some similarities, in terms of strength and nature of the relationship between mineral magnetic concentration and textual properties. Based on the results of a mathematical sedimentunmixing model (Booth, 2002), this is most likely due to the fact that Carmarthen Bay sediments acts as the primary source $(\sim 77 \%)$ of sediments in the Gwendraeth Estuary. Differences between the Carmarthen Bay and the Gwendraeth Estuary may be due to the 
Gwendraeth Estuary being influenced by other sediment sources (Gwendraeth Fach River $(\sim 13 \%)$ and Gwendraeth Fawr River $(\sim 10 \%))$. However, in addition to this, since the magnitude of the $\chi_{\text {ARM }}$ values of the estuary samples are greater than those of the sources and since the measure of this parameter is approximately proportional to the concentration of ferrimagnetic grains in the stable single domain size range (Maher, 1988), it is interpreted that authigenic greigite (Oldfield, 1999a,b) and/or bacterial magnetite (Petermann and Bleil, 1993; Hesse and Stolz, 1999) also contributes to the direction and significance of the relationship between magnetic concentration and texture in the estuary (Booth, 2002).

The Gwendraeth Fach and Gwendraeth Fawr rivers drain contrasting geologies (Gwendraeth Fach River-Devonian Sandstones; Gwendraeth Fawr River-Carboniferous Coal Measures) and their sediment load has a primarily detritus origin (Booth, 2002). Hence, in the main, the magnetic mineral assemblage is deemed to be predominately detrital in nature. However, although relatively low-key, both rivers have been subject to different anthropogenic uses in the historical past. For instance, the Gwendraeth Fawr River was employed for transporting anthracite coal by wooden barges ( 1760 s) from the South Wales coalfield (Morris, 1970) and the banks of the Gwendraeth Fach River was the site of a tinplate rolling mill near Kidwelly (Ludlow, 1991). The location of the latter industry and the nature of the manufacturing could offer an explanation as to why none of the magnetic concentration parameters for the Gwendraeth Fach River are related to the textural parameters. Electron microscope analysis has shown the presence of metal-rich, clay to fine sand size, spherical particles to be present in significant proportions in the Gwendraeth Fach River, but not the Gwendraeth Fawr River (Booth, 2002). Their appearance is similar in size, shape and chemistry to combustion-generated particles (Swaine, 1994; Hanesch and Peterson, 1999). It is widely known that coal combustion produces fly-ash particles displaying a remarkable degree of sphericity (Singh and Rawat, 1995), ranging from 1 to $2000 \mu \mathrm{m}$ (Krajickova and Mejstrik, 1984), and coated with various metaloxides, which form magnetite, haematite and maghemite minerals (Del Monte and Sabbioni, 1987; Singh and Rawat, 1995). Therefore, it is possible that past industrial emissions have imparted a non-particle size specific overprint on the magnetic concentration signature of contemporary sediments in the river, with anthropogenically derived pollutants occupying a wide size range. However, this said, it must be remembered that the study area represents a mainly typical detrital system. Therefore, the diverse mineral magnetic versus particle size relationships displayed here could occur in similar systems.

\section{Conclusion}

In addressing the two methodological questions posed earlier, the results presented here do indicate that mineral magnetic data can be used as a particle size proxy. However, this should only be attempted with caution as the relationship between magnetic concentration parameters (e.g. $\chi_{\text {LF, }} \chi_{\text {ARM }}$ and SIRM) and particle size properties are not necessarily 'universal'. These data demonstrate the relationship between mineral magnetic concentration measurements and textural properties can be different for particular sedimentary environments even within the same overall sedimentary system and, in some circumstances, the mineral magnetic approach can be unsuitable as a particle size proxy.

As a consequence, it is a recommended that the nature of the relationship between magnetic and textural properties should be explored fully for the particular sedimentary environment and individual field setting, before using magnetic measurements as a proxy for particle size. Where such a preliminary study demonstrates that a strong correlation exists, mineral magnetic measurements can then offer considerable potential as a particle size proxy of use in geochemical, sediment transport and sediment provenance studies. However, it is recommended that future work demonstrates whether fractionated samples and geochemical evidence can support these findings.

\section{Acknowledgements}

This research forms part of the staff development programme, funded by the School of Applied Sciences at the University of Wolverhampton, and 
CAB would like to acknowledge receipt of a sabbatical period granted by the University Research Committee. All authors would like to thank Patrick McLaren and Dusan Markovic of GeoSea ${ }^{\circledR}$ (Canada) Consulting and David Luckhurst, Andrew Black and Martin Fenn of the University of Wolverhampton for collecting sediment samples. This research is also indebted to Lisa Booth for help provided with laboratory analyses throughout this research. Finally, all authors would like to acknowledge the contribution of two anonymous reviewers who provided useful comments on an earlier draft of this paper.

\section{References}

Ackermann F. A procedure for correcting the grain size effects in heavy metal analyses of estuarine and coastal sediments. Environ Technol Lett 1980;1:518-27.

Ackermann F, Bergmann H, Schleichert U. Monitoring of heavy metals in coastal and estuarine sediments - a question of grain size: $<20 \mu \mathrm{m}$ versus $<60 \mu \mathrm{m}$. Environ Technol Lett 1983; $4: 317-28$.

Al-Ghadban AN. Sediment Transport in Carmarthen Bay, Unpublished $\mathrm{PhD}$ thesis, University of Wales; 1986.

Araujo M, Fatima D, Bernard PC, van Grieken RE. Heavy metal contamination in sediments from the Belgian coast and Scheldt Estuary. Mar Pollut Bull 1988;19:269-73.

Arkell B, Leeks G, Newson M, Oldfield F. Trapping and tracing: some recent observations of supply and transport of coarse sediment from upland Wales. Spec Pub Int Assoc Sedimentol 1983;6:107-19.

Aston SR, Assinder DJ, Kelly M. Plutonium in inter-tidal coastal and estuarine sediments in the Northern Irish Sea. Estuar Coast Shelf Sci 1985;20:761-71.

Barrie JV. Hydrodynamic factors controlling the distribution of heavy minerals (Bristol Channel). Estuar Coast Shelf Sci 1981;12:609-19.

Bonnett PJP, Appleby PG, Oldfield F. Radionuclides in coastal and estuarine sediments from Wirral and Lancashire. Sci Total Environ 1988;70:215-36.

Booth CA. Sediment-Source-Linkages in the Gwendraeth Estuary, South Wales, based on mineral magnetic analyses. Unpublished PhD thesis. University of Wolverhampton; 2002.

Camacho-Ibar VF, McEvoy J. Total PCBs in Liverpool Bay sediments. Mar Environ Res 1996;41:241-63.

Cauwet G. Influence of sedimentological features on the distribution of trace metals in marine sediments. Mar Chem 1987;22:221 - 34 .

Chan LS, Yeung CH, Yim WWS, Or OL. Correlation between magnetic susceptibility and distribution of heavy metals in contaminated sea-floor sediments of Hong Kong Harbour. Environ Geol 1998;36:77-86.

Christiansen C, Bartholdy J, Kunzendorf H. Effects of morphological changes on metal accumulation in a salt marsh sediment of the Skallingen Peninsula, Denmark. Wetlands Ecol Manag 2002;10:11-23.

Clifton J, McDonald P, Plater A, Oldfield F. Relationships between radionuclide content and textural properties in Irish Sea intertidal sediments. Water Air Soil Pollut 1997;99:209-16.

Clifton J, McDonald P, Plater A, Oldfield F. Derivation of a grainsize proxy to aid the modelling and prediction of radionuclide activity in saltmarshes and mud flats of the Eastern Irish Sea. Estuar Coast Shelf Sci 1999;48:511-8.

Collins M. Sediment transport in the Bristol channel: a review. Proc Geol Assoc 1987;98:367-83.

Covelli S, Fontolan G. Application of a normalisation procedure in determining regional geochemical baselines. Environ Geol 1997;30:34-45.

Dearing J. Magnetic susceptibility. In: Walden J, Smith JP, Oldfield F, editors. Environmental magnetism, a practical guide, quaternary research association. Technical Guide, vol. 6; 1999. p. 35-62.

de Groot AJ, Zschuppe KH, Salomons W. Standardisation of methods of analysis for heavy metals in sediments. Hydrobiologia 1982;92:689-95.

Del Monte M, Sabbioni C. Discussion: characterisation of individual fly ash particles emitted from coal- and oil-fired power plants. Atmos Environ 1987;21:2737-8.

Ergin M, Kazan B, Ediger V. Source and depositional controls on heavy metal distribution in marine sediments of the Gulf of Iskenderun, East Mediterranean. Mar Geol 1996;133:223-39.

Evans DJ, Thompson MS. The geology of the central Bristol channel and the Lundy area, SW approaches, British Isles. Proc Geol Assoc 1979;90:1-14.

Fernandez Caliani JC, Ruiz Munoz F, Galan E. Clay mineral and heavy metal distributions in the lower estuary of Huelva and adjacent Atlantic shelf, SW Spain. Sci Total Environ 1997; 198:181-200.

Forstner U, Salomons W. Trace metal analysis on polluted sediments: Part 1 Assessment of sources and intensities. Environ Technol Lett 1980;1:494-505.

French PW. Seasonal and inter-annual variation of selected pollutants in modern intertidal sediments, Aust Cliff, Severn Estuary. Estuar Coast Shelf Sci 1993;37:213-9.

Hanesch M, Peterson N. Magnetic properties of a recent parabrown-earth from southern Germany. Earth Planet Lett 1999; 169:85-7.

Hesse P, Stolz JF. Bacterial magnetite and the Quaternary climate record. In: Maher BA, Thompson R, editors. Quaternary climates, environments and magnetism. Cambridge University Press; 1999. p. 163-98.

Hornung H, Krum MD, Cohen Y. Trace metal distribution in sediments and benthic fauna of Haifa Bay, Israel. Estuar Coast Shelf Sci 1989;29:43-56.

Hutchinson SM, Prandle D. Siltation in the saltmarsh of the Dee Estuary derived from ${ }^{137} \mathrm{Cs}$ analysis of shallow cores. Estuar Coast Shelf Sci 1994;38:471-8.

Jago CF. Contemporary accumulation of marine sand in a macrotidal estuary, southwest Wales. Sediment Geol 1980;26:21-49.

Jago CF, Hardisty J. Sedimentology and morphodynamics of a macrotidal beach, Pendine Sands, SW Wales. Mar Geol 1984;60:123-54. 
Jones PJC. The recent sedimentology of the Towy Estuary, Dyfed, South Wales. Unpublished PhD thesis. University of London; 1977.

Jones B, Turki A. Distribution and speciation of heavy metals in surficial sediments from the Tees Estuary, North-east England. Mar Pollut Bull 1997;34:768-79.

Klamer JC, Hegeman WJM, Smedes F. Comparison of grain size correction procedures for organic micropollutants and heavy metals in marine sediments. Hydrobiologia 1990; 208:213-20.

Krajickova A, Mejstrik V. The effect of fly ash particles on the plugging stomata. Environ Pollut 1984;36:83-93.

Langston WJ. Metals in sediments and benthic organisms in the Mersey Estuary. Estuar Coast Shelf Sci 1986;23:239-61.

Lapp B, Balzer W. Early diagenesis of trace metals used as an indicator of past productivity changes in coastal sediments. Geochim Cosmochim Acta 1993;57:4639-52.

Lepland A, Stevens RL. Mineral magnetic and textural interpretations of sedimentation in the Skagerrak, eastern North Sea. Mar Geol 1996;135:51-64.

Loring DH. Lithium - a new approach for the granulometric normalisation of trace metal data. Mar Chem 1990;29: $155-68$.

Ludlow ND. The first Kidwelly tinplate works: an arachaeological and technological history. In: James H, editor. Sir gar: studies in Carmarthenshire history, carmarthenshire antiquarian society. Monograph Series, vol. 4; 1991. p. 79-100. Carmarthen.

Maher BA. Magnetic properties of some synthetic sub-micron magnetites. Geophys J 1988;94:83-96.

Maher BA, Thompson R. Quaternary climates, environments and magnetism. Cambridge University Press; 1999. 383 pp.

McCubbin D, Leonard KS, Maher BA, Hamilton EI. Association of ${ }^{210} \mathrm{Po}\left({ }^{210} \mathrm{~Pb}\right),{ }^{239+240} \mathrm{Pu}$ and ${ }^{241} \mathrm{Am}$ with different mineral fractions of a beach sand at Seascale, Cumbria, UK. Sci Total Environ 2000;254:1-15.

McLaren P. Sediment transport analysis $\left(\mathrm{STA}^{\circledR}\right)$ of Carmarthen Bay in support of the Bristol Channel marine aggregates resources and constraints research project. GeoSea ${ }^{\circledR}$ Consulting (Canada) Ltd. Report for Posford Duvivier Engineering and Environmental Consultants with ABP Research and Consultancy; 1999. $18 \mathrm{pp}$.

Mercer T. Surveys of harbours, rias and estuaries in southern Britain: Taf, Tywi and Gwendraeth Estuaries. Nature Conservancy Council, CSD. Report No. 1113; 1990. 38 pp.

Middleton R, Grant A. Heavy metals in the Humber Estuary: Scrobicularia clay as a pre-industrial datum. Proc Yorks Geol Soc 1990;48:75-80.

Morris WH. The canals of the Gwendraeth Valley (pt 1). Carmarthens Antiq 1970;6:55-87.

Oldfield F. Environmental magnetism; the range of applications. In: Walden J, Smith JP, Oldfield F, editors. Environmental magnetism, a practical guide, quaternary research association. Technical Guide, vol. 6; 1999a. p. 212-22.

Oldfield $\mathrm{F}$. The rock magnetic identification of magnetic mineral and grain size assemblages. In: Walden J, Smith JP, Oldfield F, editors. Environmental magnetism, a practical guide, quaternary research association. Technical Guide, vol. 6; 1999b. p. 98-112.
Oldfield F, Yu L. The influence of particle size variations on the magnetic properties of sediments from the north-eastern Irish Sea. Sedimentology 1994;41:1093-108.

Oldfield F, Maher BA, Donoghue J, Pierce J. Particle size related, mineral magnetic source sediment linkages in the Rhode River catchment, Maryland, USA. Journal of the Geological Society (London) 1985;142:1035-46.

Oldfield F, Richardson N, Appleby PG, Yu L. ${ }^{241} \mathrm{Am}$ and ${ }^{137} \mathrm{Cs}$ activity in fine grained saltmarsh sediments from parts of the NE Irish Sea shoreline. J Environ Radioact 1993;19:1-24.

Oldfield F, Appleby PG, van der Post KD. Problems of core correlation, sediment source ascription and yield estimation in Ponsonby Tarn, West Cumbria, UK. Earth Surf Processes Landf 1999;24:975-92.

Petermann H, Bleil U. Detection of live magnetotactic bacteria in South Atlantic deep-sea sediments. Earth Planet Sci Lett 1993;117:223-8.

Petrovsky E, Kapicka A, Zapletal K, Sebestova E, Spanila T, Dekkers MJ, et al. Correlation between magnetic parameters and chemical composition of lake sediments from Northern Bohemia-Preliminary Study. Phys Chem Earth 1998;23: $1123-6$.

Russell MA, Walling DE, Hodgkinson RA. Suspended sediment sources in two small lowland agricultural catchments in the UK. J Hydrol 2001;252:1-24.

Salomons W, Forstner U. Trace metal analysis on polluted sediments: Part 2. evaluation of environmental impact. Environ Technol Lett 1980;1:506-17.

Schmidt AM, Von Dobeneck T, Bleil U. Magnetic characterisation of Holocene sedimentation in the South Atlantic. Palaeoceanography $1999 ; 14: 465-81$.

Singh BK, Rawat NS. Characterisation of coal fly ash by FTIR, XRD and SEM. Indian J Eng Mater Sci 1995;2:241-4.

Swaine DJ. Trace elements in coal and their dispersal during combustion. Fuel Process Technol 1994;39:121-37.

Syvitski JPM. Principles, methods and application of particle size analysis. Cambridge: Cambridge University Press; 1991. 368 pp.

Szava-Kovats RC. Outlier-resistant errors-in-variables regression: anomaly recognition and grain-size correction in stream sediments. Appl Geochem 2002;17:1149-57.

Thomas RL. The distribution of mercury in the sediment of Lake Ontario. Can J Earth Sci 1972;9:636-51.

Thompson R, Oldfield F. Environmental magnetism. Allen and Unwin; 1986. 227 pp.

Thorne LT, Nickless G. The relation between heavy metals and particle size fraction within the Severn Estuary (UK) intertidal sediments. Sci Total Environ 1981;19:207-13.

Tucker M. Techniques in sedimentology. Oxford: Blackwell Scientific Publications; 1991. 394 pp.

Velegrakis AF, Brand C, Collins MB, Cooper WS. Geology and Geomorphological Evolution of the Severn Estuary and Bristol Channel, Bristol Channel Marine Aggregates: Resources and Constraints Research Project, SUDO Technical Report 97/14/C; 1999.

Walden J. Sample collection and preparation. In: Walden J, Smith JP, Oldfield F, editors. Environmental magnetism, a 
practical guide, quaternary research association. Technical Guide, vol. 6; 1999. p. 26-34.

Walden J, Smith JP, Dackombe RV, Rose J. Mineral magnetic analyses of glacial diamicts from the Midland Valley of Scotland. Scott J Geol 1995;31:79-89.

Walden J, Slattery MC, Burt TP. Use of mineral magnetic measurements to fingerprint suspended sediment sources: approaches and techniques for data analysis. J Hydrol 1997;202:353-72.

Walden J, Smith JP, Oldfield F. Environmental magnetism, a practical guide. Quaternary research association. Technical Guide, vol. 6; 1999. 243 pp.

Wheeler AJ, Oldfield F, Orford JD. Sedimentology and postdepositional controls on magnetic signals from saltmarshes on the north-west coast of Ireland. Sedimentology 1999;46:545-58.

White K, Walden J, Drake N, Eckardt F, Settle J. Mapping the iron oxide content of dune sands, Namib Sand Sea, Namibia, using Landsat Thematic Mapper data. Remote Sens Environ 1997;62:30-9.
Williams SC, Simpson HJ, Olsen CR, Bopp RF. Sources of heavy metals in sediments of the Hudson River Estuary. Mar Chem 1978;6:195-213

Xie S, Dearing JA, Bloemandal J, Boyle JF. Association between the organic matter content and magnetic properties in street dust, Liverpool, UK. Sci Total Environ 1999;241:205-14.

Xie S, Dearing JA, Bloemandal J. The organic matter content of street dust in Liverpool, UK and its association with dust magnetic properties. Atmos Environ 2000;34:269-75.

Zhao Y, Marriott S, Rogers J, Iwugo K. A preliminary study of heavy metal distribution on the floodplain of the River Severn, UK by a single flood event. Sci Total Environ 1999;243:219-31.

Zhang W, Yu L, Hutchinson SM. Diagenesis of magnetic minerals in the intertidal sediments of the Yangtze Estuary, China, and its environmental significance. Sci Total Environ 2001;266:160-75. 